\title{
Structure and Thermal Behaviour of BSCF-SDC-Ag Composite Cathode for Solid Oxide Fuel Cell
}

\author{
U.A. Yusop, K.H. Tan, H.A. Rahman
}

\begin{abstract}
Solid oxide fuel cell (SOFC) component has always under development to enhance catalytic activity. Components such as anode, cathode and electrolyte must have better structure and behavior for good SOFC performance. Traditional $\mathrm{Ba}_{0.5} \mathrm{Sr}_{0.5} \mathrm{Co}_{0.8} \mathrm{Fe}_{0.2} \mathrm{O}_{3-\delta}$ (BSCF) cathode in solid oxide fuel cell application has been deterred several inappropriate circumstances such as high thermal expansion coefficient (TEC) and chemical instability. $\mathrm{Sm}_{0.2} \mathrm{Ce}_{0.8} \mathrm{O}_{1.9}$ (SDC) electrolyte and Silver (Ag) are added into BSCF to overcome the problem and has better material characterization and thermal stability, The composite cathode powder BSCF-SDC was prepared by high speed ball milling technique with mixture of 50wt\% BSCF and 50wt\% SDC commercial powder. The powders were then dried and calcined at $950^{\circ} \mathrm{C}$ for 2 hour. Silver (Ag) with $1 w t \%$, 3wt $\%$ and $5 w t \%$ were milled respectively with BSCF-SDC by low speed ball milling technique. The developed composite cathode was then examined by $X$-ray powder diffraction (XRD), Fourier transform infrared spectroscopy (FTIR), dilatometer and Thermogravimetric Analysis (TGA). The vivid distinct phase of BSCF, SDC and Ag and absence of additional secondary phase was confirmed by XRD analysis indicating good phase structure compatibility. This also assured that less chemical reaction was happened during low speed milling process for BSCF-SDC-Ag as minor secondary phases are detected. However, milling process at high speed and high calcination temperature did destruct single phase of BSCF in BSCF-SDC composite cathode. However, Ag obtains its role to retain back the BSCF crystalline phase. The higher the percent of Ag added, the higher the BSCF peak retain. The absence of addition bonding in FTIR analysis demonstrating excellent structure compatibility of BSCF, SDC and Ag during milling process. There was no significant additional bonding appeared in BSCF-SDC-Ag after milling process. The thermal expansion coefficient (TEC) were determined using dilatometer, manifesting closer TEC mismatch between BSCF-SDC-Ag cathode composite and SDC electrolyte compared to BSCF-SDC. TEC is essential to be matched as it could prevent spallation during elevated operation temperature of SOFC. TGA analysis indicated cathode composite experiencing very less changes of weight when it was heated up $1000^{\circ} \mathrm{C}$. BSCF is revealed of decomposition occurring
\end{abstract}

Revised Manuscript Received on December 30, 2019.

* Correspondence Author

U.A. Yusop, Faculty of Mechanical and Manufacturing Engineering, Universiti Tun Hussein Onn Malaysia, Batu Pahat, Malaysia. Email: umira_yusop@yahoo.com

K.H. Tan, Faculty of Mechanical and Manufacturing Engineering, Universiti Tun Hussein Onn Malaysia, Batu Pahat, Malaysia. Email: tkh.nov@gmail.com

H.A. Rahman*, Faculty of Mechanical and Manufacturing Engineering, Universiti Tun Hussein Onn Malaysia, Batu Pahat, Malaysia. Email: hamimah@uthm.edu.my

(C) The Authors. Published by Blue Eyes Intelligence Engineering and Sciences Publication (BEIESP). This is an open access article under the CC BY-NC-ND license (http://creativecommons.org/licenses/by-nc-nd/4.0/) after $800^{\circ} \mathrm{C}$. Result revealed that $\mathrm{Ag}$ exhibited desirable thermal and structure compatibility with BSCF-SDC as promising SOFC cathode which beneficial from medium scale automobile to high scale power plant application.

Keywords: BSCF composite, Cathode, SOFC

\section{INTRODUCTION}

\section{Solid Oxide Fuel Cell (SOFC) is an environment friendly} electric generator devices comprising anode, electrolyte and cathode. Oxidation process takes part at cathode to deliver oxygen ions for hydrogen anode reduction in solid oxide fuel cell [1]. Substantial studies on cathode performance and materials compatibility has always been a practical issue to settle down when operating temperature of SOFC is lowered down from over $1000^{\circ} \mathrm{C}$. Co based perovskite materials are ultimate candidate for cathode in SOFC because of its mixed ionic and electronic conductor (MIEC) which possesses high conductivity and good catalytic activity such as $\mathrm{La}_{0.6} \mathrm{Sr}_{0.4} \mathrm{Co}_{0.2} \mathrm{Fe}_{0.8} \mathrm{O}_{3-\delta}$ (LSCF) and $\left(\mathrm{La}_{0.85} \mathrm{Sr}_{0.15}\right)_{0.9} \mathrm{MnO}_{3-\delta}$ (LSM). In MIEC cathode, the catalytic reaction extends from traditionally triple phase boundary (TPB) to entire electrode gas interface [2]. Recently, $\mathrm{Ba}_{0.5} \mathrm{Sr}_{0.5} \mathrm{Co}_{0.6} \mathrm{Fe}_{0.4} \mathrm{O}_{3-\delta}$ (BSCF) has been presented as new developed cathode material which is having consistent electrochemical satisfactory at both singer and dual chamber [3]. BSCF attracts great research attention from its remarkable low area specific resistance at low to intermediate compared to others MIEC perovskite cathodes and outstanding electrochemical performance [4]. However, BSCF is suffocating thermal expansion mismatch and instable material compatibility in oxygen environment $[5,6]$. One approach to improve those issues is incorporating electrolyte material into cathode. $\mathrm{La}_{0.6} \mathrm{Sr}_{0.4} \mathrm{Co}_{0 .}{ }_{2} \mathrm{Fe}_{0.8} \mathrm{O}_{3-\delta}-$ $\mathrm{Ce}_{0.8} \mathrm{Sm}_{0.2} \mathrm{O}_{1.9}$ (LSCF-SDC) and $\mathrm{La}_{0.6} \mathrm{Sr}_{0.4} \mathrm{Co}_{0.2} \mathrm{Fe}_{0.8} \mathrm{O}_{3-\delta}-$ $\mathrm{Ce}_{0.9} \mathrm{Gd}_{0.1} \mathrm{O}_{1.95}$ (LSCF-GDC) were developed with proved material properties and electrical performance improvement [7, 8]. BSCF-SDC had been rarely studied and reported that the thermal expansion coefficient (TEC) and electric conductivity were improved slightly and it was still open up for further investigation. Developed BSCF-SDC indicating 30.1\% TEC difference from SDC electrolyte which did not fulfill $10-20 \%$ acceptable range $[9,10]$ In this paper, BSCF-SDC was modified by incorporating several amount of silver (Ag) to generate series composite materials of BSCF-SDC-Ag in order to achieve better material characterization and thermal behavior. Optimization of cathode composite material was investigated in comparison with BSCF-SDC. 


\section{METHODOLOGY}

(1) BSCF-SDC composites cathode powder were developed by mixing 1:1 ratio of commercial BSCF powder (Sigma Aldrich) and commercial SDC powder (Sigma Aldrich) ball milling method. The milling process was taken at $550 \mathrm{rpm}$ for 2 hours in ethanol [10].

(2) The slurry was dried in oven for overnight. The process follows the previous study parameters. Then dried powder was grounded in an agate mortar and calcined at $950^{\circ} \mathrm{C}$ for 2 hours [11].

(3) Incorporating of $1 \%, 3 \%$ and $5 \%$ of Ag powder was obtained from total weight of BSCF-SDC powder. The mixing as done by 150 rpm dry milling technique for 0.5 hour obtaining BSCF-SDC-Ag composite cathode.

Purity phase and each crystalline structure of composite cathodes were conducted by X-ray powder diffractometer, XRD (Shimadzu XRD-6000, D8-Advance, Bruker, German) with $\mathrm{Cu} \mathrm{K} \alpha$ radiation $(\lambda=0.15418)$. The weight loss of composite cathode as function of temperature were carried out by thermogravimetric (TG) measurements up to $1000^{\circ} \mathrm{C}$ in air at heating rate of $5^{\circ} \mathrm{C} / \mathrm{min}$ (TGA/SDTA, Linseis, Germany). Fourier Transform Infrared Spectroscopy (FTIR) machine (Perkin Elmer Spectrum 100, USA) was applied to analyse the chemical bonding of BSCF composite cathode powders. The BSCF composite cathodes were made into cylindrical sample and tested in dilatometer (Netzsch DIL 402C, Germany) upon heating from room temperature to $900^{\circ} \mathrm{C}$ at $5^{\circ} \mathrm{C} / \mathrm{min}$.

\section{RESULT AND DISCUSSION}

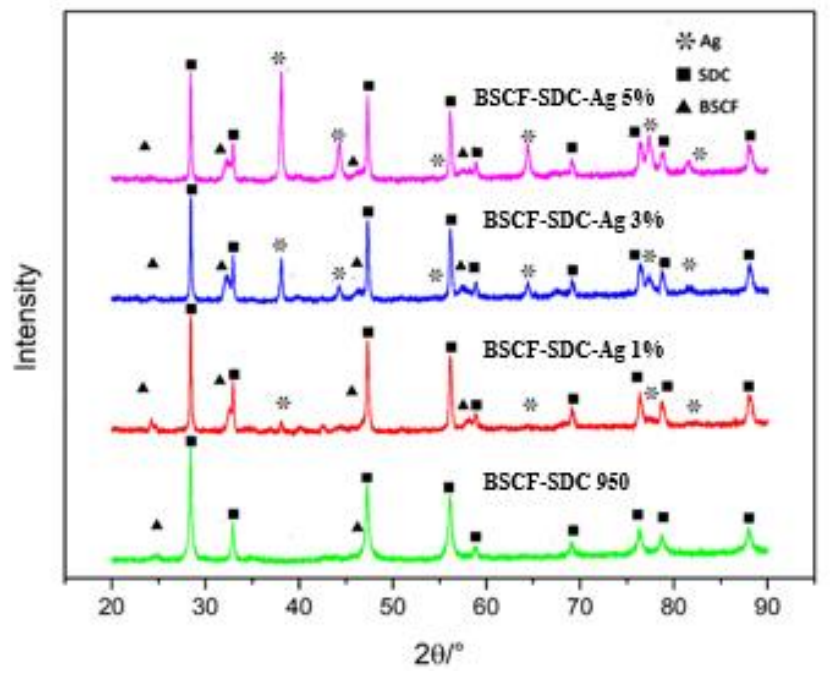

Fig. 1: XRD spectra for BSCF composite cathodes

Fig. 1 displays XRD patterns of BSCF-SDC after calcined at $950^{\circ} \mathrm{C}$ and addition of $1 \%, 3 \%$, and $5 \%$ of $\mathrm{Ag}$ into BSCF-SDC. BSCF and SDC was accorded to the XRD BSCF JCPDS No. 79-5253 and SDC JCPDS No. 75-0158 while Ag was accorded XRD JCPDS No. 04-0783. BSCF exhibited cubic lattice, SDC and Ag exhibited face center cubic lattice. SDC lattices was apparently demonstrating its distinct crystalline phase for all composite cathode after BSCF-SDC was calcined at $950^{\circ} \mathrm{C}$. Moreover, BSCF-SDC phase crystalline phase was not affected by Ag addition through the milling process. Adding of Ag did not generate secondary phase or impurities in the BSCF composite. Furthermore, it can be observed that higher the amount of Ag addition, higher the intensity of Ag XRD intensity. However, it was vividly judged that serious interaction between BSCF-SDC composite and heat treatment environment had occurred when heat treatment was conducted on $950^{\circ} \mathrm{C}$. The BSCF lattice lowered down its intensity which probably A-site $\mathrm{Ba}^{2+}$ ions chemically reacted with $\mathrm{CO}_{2}$ in air which had been reported in previous studied [11]. It formed impurity phases of $\mathrm{BaCO}_{3}$. These minor impurity could be observed much in BSCF composite cathode However, BSCF-SDC after calcined at $950^{\circ} \mathrm{C}$ had removed the secondary phase and recover BSCF crystalline phase at minimum $900^{\circ} \mathrm{C}$ [12]. The introduction of $\mathrm{Ag}$ into BSCF-SDC had also assisted retaining BSCF crystalline phase especially peaks at $33.6^{\circ}$ and $47.2^{\circ}$. The BSCF peaks was more apparent when Ag incorporation was increased. Secondary $\mathrm{BaCO}_{3}$ phase was slightly appeared in all BSCF composite cathode as can be proved in FTIR analysis.

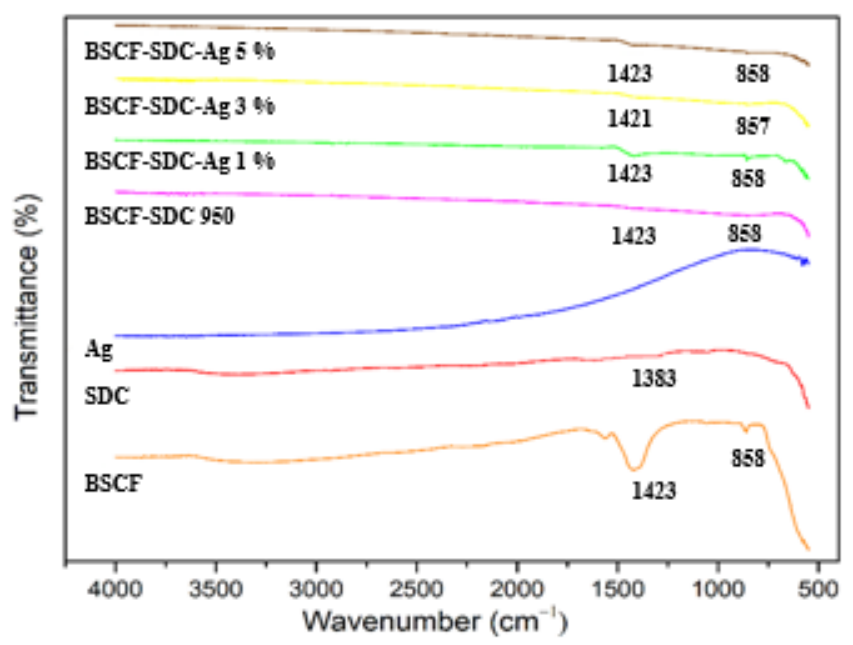

Fig 2. FTIR spectra for BSCF composite cathodes

Fig.2 shows the present of carbonate bond in BSCF-SDC composite. Carbonate phase was observed in BSCF commercial powder in wavenumber of $1424 \mathrm{~cm}^{-1}$ and 858 $\mathrm{cm}^{-1}$. It assured that there were impurities in pure BSCF powders. This could be interaction between BSCF and $\mathrm{CO}^{2}$ even in ambient temperature or a prolonged time. Commercial SDC presented no carbonate bond found in the FTIR spectra. Also, BSCF-SDC composite cathode assembled no others organic bond except of very insignificant carbonate bond shown in spectra $1423 \mathrm{~cm}^{-1}$ and $858 \mathrm{~cm}^{-1}$. This was contributed to calcination at high temperature which had been removing all impurities that appeared in BSCF-SDC including $\mathrm{BaCO}_{3}$ during the milling process. It could be seen that milling process of BSCF-SDC-Ag had created slight carbonate spectra observed in the same wavenumber for all $1 \%, 3 \%$, and $5 \%$. This was owing to low speed milling process, also generated heat which provoked reaction between BSCF and SDC.

Published By: Blue Eyes Intelligence Engineering

\& Sciences Publication 


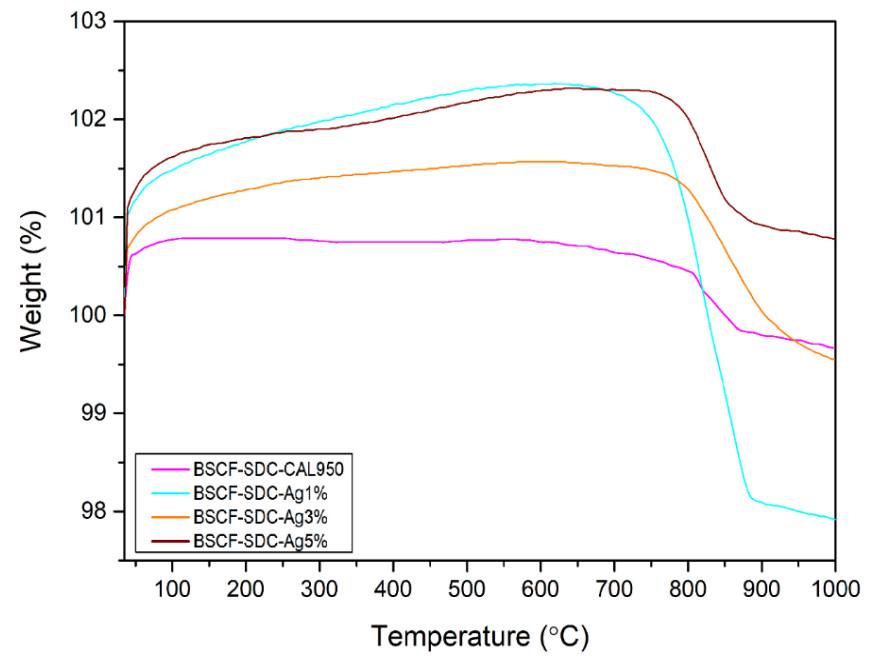

Fig. 3: The weight change of various BSCF cathode composites as function of temperature

The weight change of BSCF cathode composites was recorded versus temperature heating up from room temperature to $1000^{\circ} \mathrm{C}$ as shown in Fig. 3. The graph illustrated weight increment for all BSCF composite cathodes. The weight increment was obvious for BSCF composite cathodes with Ag incorporation. The weight increased from $30^{\circ} \mathrm{C}$ to $800^{\circ} \mathrm{C}$ which denoted slight weigh increment from 0 to $2 \%$ increment. BSCF-SDC weight had been increased but it was very insignificant below than $1 \%$ and then, the weight persists the same until temperature reached $800^{\circ} \mathrm{C}$. Upon elevated temperature heating, BSCF was chemically interact with carbon dioxide in air and form minor secondary metal carbonate. After $800^{\circ} \mathrm{C}$, the weight loss back to approximate original weight it was the temperature where secondary metal carbonate was removed. Moreover, the weight loss after $800^{\circ} \mathrm{C}$ also indicated the starting crystalline phase recovery of BSCF as reported in previous study no matter it was heating in conventional method or in microwave [13]. This was investigated that BSCF cathode composites were appropriate utilized in low and intermediate temperature application.

Table 1: Average TEC value for BSCF composite cathode at variant temperature

\begin{tabular}{|c|c|c|c|}
\hline \multicolumn{4}{|c|}{$\operatorname{TEC}\left(\times 10^{-6} / \mathrm{K}\right)$} \\
\hline Samples & $\left(30^{\circ} \mathrm{C}-600^{\circ} \mathrm{C}\right)$ & $\begin{array}{l}\left(30^{\circ} \mathrm{C}-\right. \\
\left.800^{\circ} \mathrm{C}\right)\end{array}$ & $\begin{array}{l}\left(30^{\circ} \mathrm{C}-\right. \\
\left.900^{\circ} \mathrm{C}\right)\end{array}$ \\
\hline SDC & 12.7 & 12.8 & 12.8 \\
\hline BSCF-SDC & 9.9 & 10.5 & 7.7 \\
\hline BSCF-SDC-Ag1\% & 10.2 & 11.8 & 6.3 \\
\hline BSCF-SDC-Ag 3\% & 9.5 & 11.0 & 7.4 \\
\hline BSCF-SDC-Ag 5\% & 8.6 & 9.3 & 3.4 \\
\hline
\end{tabular}

Table I tabulates the TEC values of all SBCF composites. Assembling TEC value at $30^{\circ} \mathrm{C}-600^{\circ} \mathrm{C}$ from Table 1 , all BSCF composites cathode indicated huge mismatch of TEC with SDC electrolyte. All BSCF composite cathode had TEC value 20\% higher than SDC electrolyte. High different must be avoided as delamination could be happened during SOFC operating and lead to degradation of SOFC electrode component [14]. Demonstrating from $30^{\circ} \mathrm{C}-800^{\circ} \mathrm{C}$, TEC for BSCF-SDC-Ag $3 \%$ was $14.8 \%$ different from SDC electrolyte. BSCF-SDC-Ag 1\% manifested the best match TEC with electrolyte with only $7.8 \%$ different form SDC TEC and this was complete within coverage of $10 \%$ different which was reported the best TEC difference [10]. However, $10 \%-20 \%$ was an acceptable range for electrode component mechanical compatibility. The average TEC values from $30^{\circ} \mathrm{C}-900^{\circ} \mathrm{C}$ for all BSCF composite cathode were not within the acceptable range as owing to decomposition of BSCF at after $800^{\circ} \mathrm{C}$ as mentioned in TGA discussion. Ag had been reported having capability to lower down the TEC of cathode composite [15-16]. Higher the amount of Ag added, lower the TEC was obtained. This is similar to Ag addition to BSCF-SDC in this study.

\section{CONCLUSION}

In conclusion, Ag was successfully incorporated into BSCF-SDC cathode by milling, showing good outcome of crystalline phase distinction, no significant existing of additional bonding and stable thermal behavior determination. Generally, BSCF-SDC-Ag 1\% and 3\% was exhibiting the best cathode characterization which having stable BSCF, SDC and Ag crystalline phase, no impurities formed, enhance thermogravimetric analysis and less than $10 \%$ thermal expansion coefficient toward electrolyte. Hence, BSCF-SDC-Ag is proved promising for SOFC cathode application which exhibits excellent material properties. Good material properties is crucial for efficient cathode catalytic activity and conductivity.

\section{ACKNOWLEDGMENT}

The authors would like to thank Universiti Tun Hussein Onn Malaysia (UTHM) for sponsoring this research under Postgraduate Research Grant (GPPS), U748.

\section{REFERENCES}

1. N. Mahato, A. Banerjee, A. Gupta, S. Omar, and K. Balani, "Progress in material selection for solid oxide fuel cell technology: A review," Progress in Materials Science, vol. 72, pp. 141-337, July 2015.

2. K. Amezawa et al., "Triple Phase Boundary Reaction in a Mixed-Conducting SOFC Cathode," ECS Transactions, vol. 77, no. 10, pp. 41-47, May 2017.

3. Y. Guo et al., "An all porous solid oxide fuel cell (SOFC): a bridging technology between dual and single chamber SOFCs," Energy \& Environmental Science, vol. 6, no. 7, pp. 2119-2123, May 2013.

4. L. Zhao, B. He, X. Zhang, R. Peng, G. Meng, and X. Liu, "Electrochemical performance of novel cobalt-free oxide $\mathrm{Ba}_{0.5} \mathrm{Sr}_{0.5} \mathrm{Fe}_{0}$. ${ }_{8} \mathrm{Cu}_{0 .} \mathrm{O}_{3-\delta}$ for solid oxide fuel cell cathode," Journal of Power Sources, vol. 195, no. 7, pp. 1859-1861, April 2010.

5. M. Ahmadrezaei, S. M. Ali, A. Muchtar, C. Tan, and M. Somalu, "Thermal Expansion Behavior," Ceramics-Silikáty, vol. 58, no. 1, pp. 46-49, March 2014.

6. O. Ravkina, A. Yaremchenko, and A. Feldhoff, "Phase separation in BSCF perovskite under elevated oxygen pressures ranging from 1 to 50 bar," Journal of Membrane Science, vol. 520, pp. 76-88, December 2016.

7. J. Harris, C. Metcalfe, M. Marr, J. Kuhn, and O. Kesler, "Fabrication and characterization of solid oxide fuel cell cathodes made from nano-structured LSCF-SDC composite feedstock," Journal of Power Sources, vol. 239, pp. 234-243, January 2013. 
8. Y. Liu, F. Wang, B. Chi, J. Pu, L. Jian, and S. P. Jiang, "A stability study of impregnated LSCF-GDC composite cathodes of solid oxide fuel cells," Journal of Alloys and Compounds, vol. 578, pp. 37-43, November 2013.

9. $\mathrm{S}$. Li et al., "Performances of $\mathrm{Ba}_{0.5} \mathrm{Sr}_{0.5} \mathrm{Co}_{0.6} \mathrm{Fe}_{0.4} \mathrm{O}_{3-\delta}-\mathrm{Ce}_{0.8} \mathrm{Sm}_{0.2} \mathrm{O}_{1.9}$ composite cathode materials for IT-SOFC," Journal of Alloys and Compounds, vol. 448, no. 1, pp. 116-121, January 2008.

10. Rahman HA, Muchtar A, Muhamad N, Abdullah H. Structure and thermal properties of $\mathrm{La} 0.6 \mathrm{Sr} 0.4 \mathrm{Co} 0.2 \mathrm{Fe} 0.8 \mathrm{O} 3-\delta$-SDC carbonate composite cathodes for intermediate-to low-temperature solid oxide fuel cells. Ceramics International. 2012;38(2):1571-6.

11. M. Chen, B. H. Kim, Q. Xu, O. J. Nam, and J. H. Ko, "Synthesis and performances of Ni-SDC cermets for IT-SOFC anode," Journal of the European Ceramic Society, vol. 28, no. 15, pp. 2947-2953, November 2008.

12. K. H. Tan et al., "Influence of Heat Treatment and Milling Speed on Phase Stability of $\mathrm{Ba}_{0.5} \mathrm{Sr}_{0.5} \mathrm{Co}_{0.8} \mathrm{Fe}_{0.2} \mathrm{O}_{3-\delta}$ Composite Cathode Solid Oxide Fuel Cell," in Key Engineering Materials, 2018, vol. 791, pp. 66-73, November 2018

13. K. H. Ng, H. A. Rahman, and S. Afandi, "Effects of milling speed and calcination temperature on the phase stability of $\mathrm{Ba}_{0.5} \mathrm{Sr}_{0.5} \mathrm{Co}_{0.8} \mathrm{Fe}_{3-8,}$, in Materials Science Forum, 2017, vol. 888, pp. 47-51, March 2017.

14. R. B. Nuernberg and M. R. Morelli, "Synthesis of BSCF perovskites using a microwave-assisted combustion method," Ceramics International, vol. 42, no. 3, pp. 4204-4211, February 2016..

15. J. Li, S. Wang, R. Liu, Z. Wang, and J. Q. Qian, "Electrochemical performance of $\left(\mathrm{Bi}_{2} \mathrm{O}_{3}\right) 1-\mathrm{x}\left(\mathrm{Er}_{2} \mathrm{O}_{3}\right) \mathrm{x}-\mathrm{Ag}$ composite material for intermediate temperature solid oxide fuel cell cathode," Solid State Ionics, vol. 179, no. 27, pp. 1597-1601, September 2008.

16. L. Agun, A. Bakar, M. Subri, S. Ahmad, A. Muchtar, and H. Abd Rahman, "Influence of Ag on Chemical and Thermal Compatibility of LSCF-SDCC for LT-SOFC," in Applied Mechanics and Materials, vol. 773, pp. 445-449, July 2015

\section{AUTHORS PROFILE}

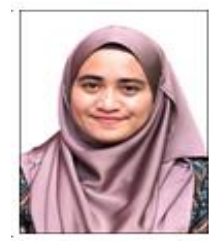

U.A. Yusup received her bachelor's degree in mechanical engineering technology (Industrial Packaging) with Honours in 2016 from University Tun Hussein Onn Malaysia (UTHM) respectively. She is currently pursuing her master's degree under the same university. She is working as general researcher assistance under Functional Composite Structure Research Group in UTHM. Along with her research journey, she gets to publish 6 technical paper in national conference and 1 technical paper in international conference. Her research work interest is fuel cell system, cathode composite, electrolyte material and electrochemical testing development. She is a student membership in Institute of Materials, Malaysia (IMM) to pursue extra knowledge for her master study.

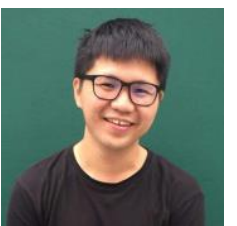

K.H. Tan received his bachelor's degree of mechanical engineering with honours at Universit Tun Hussein Onn Malaysia, Malaysia in 2016. He is starting his PhD study from 2016 under the same university in the Faculty of Mechanical \& Manufacturing Engineering. $\mathrm{He}$ is doing his research on solid oxide fuel cell (SOFC) which interesting on electrode and electrolyte material's investigation and electrochemical activity of the materials. Presently on his study, he has managed to publish 6 research papers including various international indexed journals and conferences. He is a member of Board of Engineering Malaysia (BEM) and Institute of Materials, Malaysia (IMM) in assisting of PhD journey.

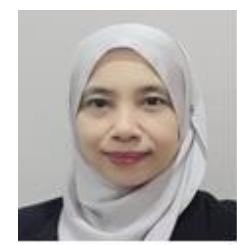

Dr. H.A Rahman is an Associate Professor in Universiti Tun Hussein Onn Malaysia (UTHM). She received her Master in materials Engineering from Universiti Sains Malaysia (1998) and $\mathrm{PhD}$ in mechanical engineering (materials) from Universiti Kebangsaan Malaysia in 2013. She is a Professional Technologist acknowledged by Malaysian Board of Technologies. Her papers have been published in International Journal of Hydrogen Energy, Ceramics International, Materials Chemistry \& Physics and so on. Her research interest lies in developing and applying composite cathode and anode materials for low temperature solid oxide fuel cell. Her research group focuses on fabrication and developing low to intermediate temperature metal supported solid oxide fuel cell via electrophoretic deposition and screen-printing low operating temperature for portable applications. 